Special issue of the 3rd International Conference on Computational and Experimental Science and Engineering (ICCESEN 2016)

\title{
Pulse Electrodeposition of Copper-Zinc Coatings from an Alkaline Bath
}

\author{
M. Kartal*, A. Alp and H. Akbulut \\ Sakarya University, Metallurgical and Materials Engineering Department, Sakarya, Turkey
}

\begin{abstract}
A copper-zinc bath containing EDTA was used for deposition of multi-functional copper-zinc coatings. Copper substrates were used for pulse electrodeposition of copper-zinc coating. Microhardness and wear resistance of copper-zinc coatings has been studied. The films were characterized by scanning electron microscopy and X-ray diffraction. EDS and EDS-dot mapping were also performed to analyse the amount and the distribution of $\mathrm{Cu}-\mathrm{Zn}$ atoms.
\end{abstract}

DOI: 10.12693/APhysPolA.132.801

PACS/topics: 81.15.Pq, 82.47.-a

\section{Introduction}

$\mathrm{Cu}$-Zn alloys have attracted attention due to their corrosion resistance and decorative applications [1-5]. Cu$\mathrm{Zn}$ electrodepositions were produced by using cyanide and non-cyanide baths, namely from electrolytic solutions based on complexing agents such as gluconate, citrate, EDTA, tartrate, sorbitol, glucoheptonate, pyrophosphate or mannitol [6-10]. Commercially, $\mathrm{Cu}-\mathrm{Zn}$ electroplating is carried out by using cyanide baths. Crack free, high quality coatings can be produced by using these cyanide baths. However, environmental and health issues of cyanide limit the use of the cyanide baths. Ethylenediaminetetraacetic acid (EDTA) was used as a complexing agent in $\mathrm{Cu}-\mathrm{Zn}$ electroplating from noncyanide baths $[1,8]$. Using EDTA as a complexing agent in the baths for coating is favourable, because, this compound acts as complexing agent for the most of the metallic ions in acid or alkaline media [8]. Thus, EDTA acts by stabilizing the ions in solution. However, depending on the metallic ions, one complex can interfere with the stability of the other, resulting in an instability of the deposition bath.

Pulse current electrodeposition is a promising technique for deposition of metals, alloys and metal matrix composites. Several studies have demonstrated that electroplating by using pulse current technique results in the production of deposits with improved mechanical properties and with more uniformly distributed metal ions, in comparison with direct current technique [11-14]. Some important equations used in pulse electrodeposition are as follows [11]:

$$
\begin{aligned}
& \text { Frequency }=\frac{1}{t_{\mathrm{on}}+t_{\mathrm{off}}}, \\
& \text { Duty cycle }=\frac{t_{\mathrm{on}}}{t_{\mathrm{on}}+t_{\mathrm{off}}} \times 100 .
\end{aligned}
$$

\footnotetext{
*corresponding author; e-mail: kartal@sakarya.edu.tr
}

In this paper, $\mathrm{Cu}-\mathrm{Zn}$ films were produced by using pulse electrodeposition in an alkaline bath and the effect of current density on the microstructure, atomic deposit dispersion and ratios were investigated.

\section{Experimental details}

The composition of the electrolyte and the plating conditions are demonstrated in Table I. Before deposition, substrates were polished with 600 mesh emery paper and further acidic treatment of the substrates was applied in a sulphuric acid solution for chemical activation.

TABLE I

Bath compositions and conditions for $\mathrm{Cu}-\mathrm{Zn}$ coating production.

\begin{tabular}{c|c}
\hline \hline Zinc sulphate $\left(\mathrm{ZnSO}_{4} \cdot 7 \mathrm{H}_{2} \mathrm{O}\right)\left[\mathrm{g} \mathrm{l}^{-1}\right]$ & 60 \\
\hline Copper sulphate $\left(\mathrm{CuSO}_{4} \cdot 5 \mathrm{H}_{2} \mathrm{O}\right)\left[\mathrm{g} \mathrm{l}^{-1}\right]$ & 45 \\
\hline Ammonium chloride $\left(\mathrm{NH}_{4} \mathrm{Cl}\right)\left[\mathrm{g}^{-1}\right]$ & 100 \\
\hline Ethylenediaminetetraacetic acid $(\mathrm{EDTA})\left[\mathrm{g} \mathrm{l}^{-1}\right]$ & 120 \\
\hline Temperature $\left[{ }^{\circ} \mathrm{C}\right]$ & 45 \\
\hline Current density $\left[\mathrm{A} / \mathrm{cm}^{2}\right]$ & $0.75,1$, \\
\hline Plating time $[\mathrm{min}]$ & $1.5,1.75$ \\
\hline Pulse on-off time $[\mathrm{ms}]$ & 90 \\
\hline $\mathrm{pH}$ & $5-5$ \\
\hline
\end{tabular}

Microstructural investigations were performed using JEOL-JSM 6060LV instrument. Rigaku D/MAX/2200/ PC model device was used for X-ray analysis at a speed of $1 \% \mathrm{~min}$, in the range between $10^{\circ}$ and $90^{\circ}$. The particle volume fractions were calculated directly using the 6060 LV SEM image analysis program, which is based on phase area method.

\section{Results and discussion}

Figure 1a shows SEM micrographs of the Cu-Zn deposits produced using different current densities. Uniform and nodular $\mathrm{Cu}-\mathrm{Zn}$ grains were deposited as shown 
in the figure. As seen from the figure, the increasing current density resulted in decreasing $\mathrm{Cu}-\mathrm{Zn}$ grains. However, at $1.75 \mathrm{~mA} / \mathrm{cm}^{2}$, grain growth mechanism had changed from granular to dendritic form. Similar results were reported by Almeida et al. [8] at higher current densities, which exhibited a low levelling degree and coarse granulometry.

Figure 1b shows the XRD patterns of pulse electrodeposited $\mathrm{Cu}-\mathrm{Zn}$, produced using different current densities. As can be seen from Fig. 1 b, Cu, CuZn and $\mathrm{Cu}_{5} \mathrm{Zn}_{8}$ phases are observed. It is also observed that the intensity of $\mathrm{Cu}_{5} \mathrm{Zn}_{8}$ peak was suppressed when the current density was increased. When the higher current densities were applied, the peak shifted to higher angles and broadening of peaks was observed, as a result of higher internal stress and decreasing of the crystallite sizes. Similarly, in our previous work [8], decreasing of crystallite sizes was observed at increasing current densities in $\mathrm{Ni} / \mathrm{MWCNT}$ pulse electrodeposition.
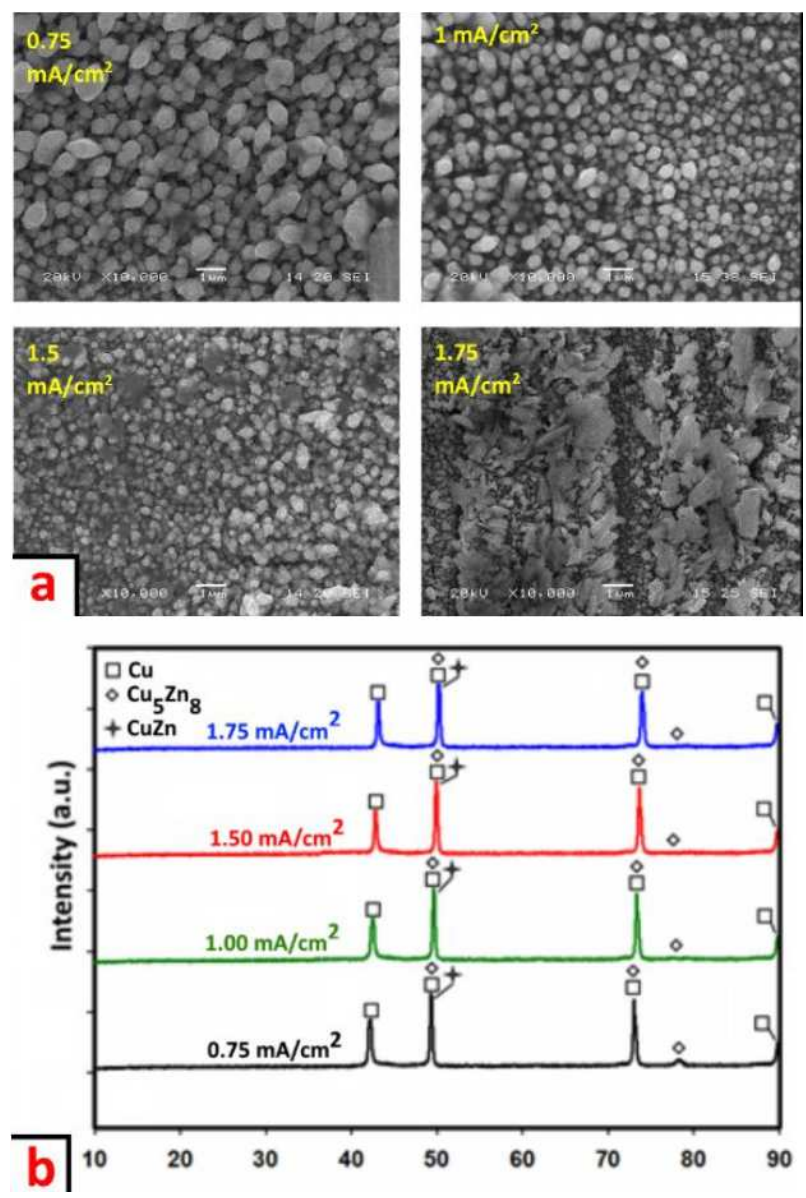

Fig. 1. (a) SEM microstructures, (b) XRD patterns of $\mathrm{Cu}-\mathrm{Zn}$ coatings produced with different current densities.

Figure 2 shows EDS dot-mapping analysis and atomic weight ratios of pulse electrodeposited $\mathrm{Cu}-\mathrm{Zn}$ coatings, produced under different current densities. As can be seen from the figure, the increasing current density resulted in decreased uniformity and appearance of zinc in the deposited layer. It is observed that zinc electrodeposition is higher at the lower current densities. $\mathrm{Cu}-\mathrm{Zn}$ crystallites randomly grow on the copper substrate and may form agglomerates. The composition and crystallite sizes strongly depend on the applied potential. If the current density is very small, there will be insufficient crystalline growth centers and the deposited layer will be rough-grained. If the current density is high, the deposited layer will be porous and soft.

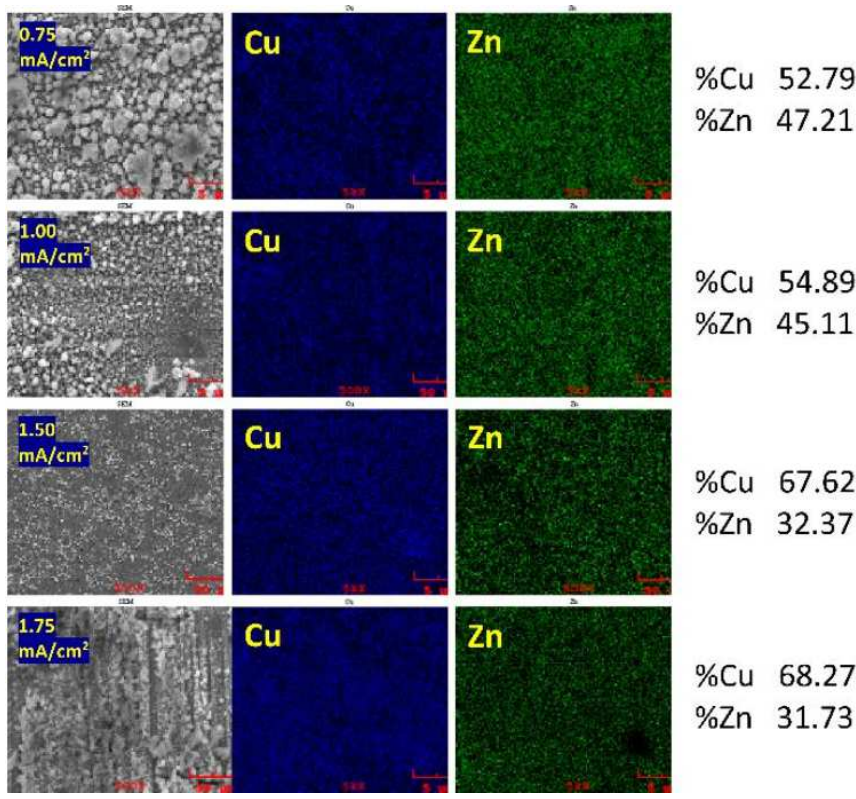

Fig. 2. SEM microstructures and EDS dot-mapping images of $\mathrm{Cu}-\mathrm{Zn}$ coatings produced with different current densities.

\section{Conclusions}

In conclusion, $\mathrm{Cu}-\mathrm{Zn}$ coatings were pulse electrodeposited using four different current rates. Increasing current density resulted in decreasing crystallite size. Up to $1.5 \mathrm{~mA} / \mathrm{dm}^{2}$ morphology was made up of granular grains and grains tend to be finer, however at $1.75 \mathrm{~mA} / \mathrm{cm}^{2}$ grain growth mechanism had changed to dendritic form. $\mathrm{Cu}: \mathrm{Zn}$ ratio was increasing with the increasing current density. It is observed that the current density plays an important role in the pulse electrodeposition of such $\mathrm{Cu}-$ Zn coatings.

\section{References}

[1] M.R.H. De Almeida, E.P. Barbano, M.F. De Carvalho, P.C. Tulio, I.A. Carlos, Appl. Surf. Sci. 333, 13 (2015).

[2] I.H. Karahan, Acta. Phys. Pol. A 128, B-432 (2015).

[3] I.H. Karahan, F. Tiltil, Acta. Phys. Pol. A 130, 282 (2016).

[4] A.S. Kadirbayeva, A.B. Bayeshov, Acta. Phys. Pol. A 128, B-458 (2015). 
[5] Y. Celik, E. Bozkurt, B. Karabulut, N. Dege, Acta. Phys. Pol. A 130, 163 (2016).

[6] I.A. Carlos, M.R.H. De Almeida, J. Electroanalyt. Chem. 562, 153 (2004).

[7] C. Ramírez, J.A. Calderón, J. Electroanalyt. Chem. 765, 132 (2016).

[8] M.R.H. De Almeida, E.P. Barbano, M.G. Zacarin, M.M. De Brito, P.C. Tulio, I.A. Carlos, Surf. Coat. Technol. 287, 103 (2016).

[9] P. De Vreese, A. Skoczylas, E. Matthijs, J. Fransaer, K. Binnemans, Electrochim. Acta 108, 788 (2013).

[10] M. Ghorbani, M. Mazaheri, K. Khangholi, Y. Kharazi, Surf. Coat. Technol. 148, 71 (2001).
[11] M. Kartal, M. Uysal, H. Gul, A. Alp, H. Akbulut, Appl. Surf. Sci. 354, 328 (2015).

[12] M. Kartal, M. Uysal, H. Gul, A. Alp, H. Akbulut, Surf. Eng. 31, 659 (2015).

[13] N.P. Wasekar, S.M. Latha, M. Ramakrishna, D.S. Rao, G. Sundararajan, Mater. Design 112, 140 (2016).

[14] M. Kartal, H. Gul, M. Uysal, A. Alp, Fuller. Nanotub. Car. N. 23, 956 (2015). 